\title{
PROTECTION OF HUMAN RIGHTS IN ARMED CONFLICTS: A REVIEW OF THE YEMENI CIVIL WAR FROM SHARIAH AND LEGAL PERSPECTIVES
}

\author{
Mohammed Ahmed Qasem Shaddad \\ PhD Student, Department of Shariah and Law, \\ Academy of Islamic Studies, \\ University of Malaya, Kuala Lumpur. \\ m.shaddad2020@yahoo.com \\ Ahmad Hidayat Buang \\ Professor, Department of Shariah and Law, \\ Academy of Islamic Studies, \\ University of Malaya, Kuala Lumpur. \\ hidayat.buang@gmail.com \\ Abdul Azeez Maruf Olayemi, \\ Post-Doctoral Research Fellow, Department of Shariah and Law, \\ Academy of Islamic Studies, \\ University of Malaya, Kuala Lumpur. \\ ma1129uk@um.edu.my
}

\begin{abstract}
This article aims to examine the level of the compliance of the Yemeni civil war with the obligation of protection of fundamental human rights under Shariah and the international laws. A combined methods of descriptive legal approach and in-depth interview techniques are adopted for the study. For the interview, six respondents were selected to answer questions on the adverse effects of the war on the economy, social affairs, health care system and most vulnerable group, as well as the level of compliance of the war with international laws. Even then, it was uncovered that the armed conflict in Yemen infringed on all the moral and legal principles of war under the Shariah and international laws. For example, the justification for the Yemeni war is not 'self-defence'
\end{abstract}


as contrary to the presumption of the laws. The interview further revealed that there is a complete infringement of fundamental human rights which constitutes a devastating consequence on the spirits of the citizens and the economic resources, in the war. It is therefore concluded that there is a necessity for a concerted effort for the charting of a modality for a gradual mitigation of the negative effects of the war and to its final ending.

Keywords: armed conflicts, ethics of war, Yemen, human rights

\section{INTRODUCTION}

The longstanding Yemeni civil war has encroached on the fundamental rights of the citizens and eroded the wealth and economy of the country (Bradley J. Cook \& Michael Stathis, 2012: 175). Although Islam is being erroneously adduced as a justification for the aggression, it is clear that the form and objective of armed conflicts in the country are antithetical to the rules and ethics of war under Islamic law. This is due to the fact that the only recognised casus belli ${ }^{1}$ for the Islamic jihād are a defence against external aggression (Ahmed Al-Dawoody, 2011: 78). In another word, jihäd is a defensive war and not a sectarian, civil or offensive war as it is being erroneously interpreted to usurp political power and bring down regimes in Yemen and some other Muslim countries today. The continuous massive destruction of both lives and economic resources in the Yemeni civil wars is a direct violation of the precepts of the Islamic religion. Islamic law does not legitimise any war except that which is for the purpose of 'self-defence' against external forces. Other circumstances in which the Shariah law allows the use minimum force for the authority is in the situation of maintenance of internal security. For instance, the authority is allowed to exercise proactive measures against the acts of civil disorder and sedition in order to safeguard the general well-being of the people and the state. In a word, organised rebellion and incitement against a constituted authority or the state are forbidden under Islamic law, especially if such action is prone to degenerate into full-blown civil wars (al-Dawoody, 2011).

Meanwhile, the participation in a war may become obligatory and compulsory on every able male Muslim under Islamic law. That is, when the war is for the purpose of defending the national territory (Khaled Abou El Fadl, 1999: 152). Even in such situation, if a call for a cease-fire is made by the aggressor, Muslim warriors must accept the offer and halt the struggle in accordance with the rules of engagement under Islamic law (Afsaruddin,

1 That is, 'Justification for War'. 
Asma, 2007: 165). Islamic law prescribed that the civilian populace and the residential areas must be protected. Thus, the concept of 'collateral damage' is unacceptable to Islam. For that reason, any destruction, damage, looting, raiding, pillaging, harming of the civilian masses, including the aged people, women, minors, disabled, noncombatant able men and any attack on the nonmilitarized zones as well as the looting of travellers and wayfarers regardless of whether they are Muslims or non-Muslims are strictly prohibited under Islamic law (Hassan Hathout, n.d.: 8).

More so, as part of Islamic ethics of war, refugees, prisoners of war, hostages, and asylum seekers must be given all necessary protection during war (Kelsay, J., 2003: 63). This also includes the protection of economic resources such as farmlands, forest, crops, livestock and factories. This is regardless whether the economic resource belongs to the enemy or not. Moreover, the use of the stoppage of water supply, hoarding of food items, medical products as a weapon of war are totally prohibited. Thus, unnecessary tenacity, doggedness, as well as treachery, and the mutilation of the enemy's body that characterised the modern warfare are strictly forbidden under Islamic law (Aboul-Enein, H. Yousuf and Zuhur, Sherifa, 2004: 22).

As a result, Islamic law prescribes that any losses that are melted to the civilian populations during a warfare must be compensated (Niaz A. Shah, 2011: 44), notwithstanding, whether the action is for the purpose of self-defence against foreign forces or the suppression of internal uprising and rebellion. The rules are applicable to all situations of war. Islamic law decrees, as well, that the measure of force that is used in a war must be in equal proportion with that of the enemy and that when a peace agreement is reached it must be honoured (Patricia Crone, 2001: 456). To be brief, under the Islamic military law and jurisprudence, it is a paramount duty on the State and its army to protect lives and economic resources during war (Kelsay, J., 2003: 63). The Islamic ethics and conducts of war are summarised in the speech of holy Prophet Muhammad SAW while addressing the Islamic soldiers on the expedition to Egypt as follows:

"You shall enter Egypt, a country where the monetary unit and bill of exchange is al-Kirat. Show them good manners. Do not forget that we have an affinity with them through marital relationships. So when you arrive in Egypt, employ many soldiers from them. They are the best soldiers on earth today. The soldiers and their spouse shall remain permanently on duty till the Day of Resurrection. Also, be kind to the Copts of Egypt; you shall take over them, but they shall be loyal and work for your success. Be 
righteous to (Christian) Copts for the sake of Allah..." (El Daly, Okasha, 2004: 18)

In the same vein, the first caliph Abū Bakr while executing the expedition of Usamah bin Zayd stated the same codes of conduct in his speech.

"Dear people (the army)! I instruct you to abide by these ten rules; so learn them well! Listen, O people, I instruct you to abide by these ten rules as your code of conduct in the war front. Do not engage in treachery and deceitfulness or diverge from the right path. Do not mutilate dead bodies. Do not attack or kill a minor, a woman, or an aged person. Neither cut down the trees, nor set them ablaze, the economic trees that bear fruit must be preserved. Do not slay any of the enemy's flock of animals unnecessarily, except for your feeding. You are likely to come across people the devotees of the monastic services (Christians); do not harm them. Leave them to their devotion..." (Fred M. Donner, 1993: 16)

A good example of the implementation of the Islamic codes of war is the treatment that the Crusaders enjoyed after they were defeated and captured by the Muslim army. The defeated Crusaders were treated with utmost kindness, friendship and charity by the Muslims. This was despite the fact that Muslims were previously inhumanly treated in the hands of the Crusaders (Weeramantry, Christopher G., 1997: 136). This is on the first hand.

On the other hand, the position of the International law is similar to that of the Islamic law, in this respect. The Article 51 of the UN Charter provides that armed assault can be used is in the situation of self-defence. It provides that 'Nothing in the present Charter shall impair the inherent right of individual or collective selfdefense if an armed attack occurs against a Member of the United Nations. ${ }^{2}$ It is very clear that both Shariah law and the international law are in tandem on the justification for legitimate Jus ad Bellum 'the use of force' by way of self-defence (Muhammad Naqib Ishan Jan, 2011: 18). The UN Charter tallies with 'Kellogg-Brian Pact, 1928' (General Treaty for the Renunciation of War or the World Peace Act, 1928) ${ }^{3}$ which was signed by UK, USA, France and Italy on August 27, 1928. The Pact banned the use of war as

2 Charter of the United Nations and Statute of the International Court of Justice, Chapter VII, Action with Respect to Threats to the Peace, Breaches of the Peace, and Acts of Aggression, Article 51, p 10.

3 General Treaty for the Renunciation of War or the World Peace Act, 1928. See, $<$ http://history.state.gov/>, accessed on 25 April 2012. 
an instrument of national policy. Another law that forbids war, except in the situation of self-defence, is the London Charter, $1945 .{ }^{4}$

Moreover, 'force' may be legitimately resorted to, under international law besides its use in 'self-defence' in the situation whereby a foreign attack is foreseeable. This is what is known as 'pre-emptive use of force' (Louis Rend Beres, 2016: 335). Thus, an Interventional or anticipatory self-defence is allowed in the circumstances where a foreign armed attack is imminent and inevitable. Nevertheless, there is an opinion that argues that the right of 'preventive self-defence' (Abraham D. Sofaer \& Kori Schake, (2016: 65) is illegitimate under international law and therefore it is not allowed (Ibid).

Furthermore, the use of force is allowed for 'collective action.' 5 An example of this was the authorization that was granted by the United Nations' Security Council for the 'collective use of force' (Ibid) in the case of the Korean war in 1950 to secure the withdrawal of North Korea from South Korea. Another example is the United Nation's Security Council Resolution 678 which authorised the use of force by all member states in cooperation with Kuwait to ensure the withdrawal of Iraqi forces from the country in 1990. The use of force in peacekeeping or humanitarian interventions is also under this concept. ${ }^{6}$

Force can also be legitimately used to protect nationals. Examples of these include the intervention of UK in Suez (1956), Israel in Entebbe (1976) and the USA in the Dominican Republic (1965), Grenada (1983) and Panama (1989) to protect their nationals. Finally, the use of force is allowed in Humanitarian Intervention. For instance, during the crisis of Kosovo in 1999, the UK in order to avoid a humanitarian catastrophe used military action for peace mission in the country. ${ }^{7}$

Conversely, the Yemeni armed conflicts that have broken out since 1985 cannot be situated under any of the situations where the use force is legitimised, and nor does it comply with the stipulated ethics of war under the Shariah and

4 Aide-Memoire, International Conference on Military Trials : London, 1945, See, $<$ http://avalon.law.yale.edu/imt/jack10.asp>, accessed on 25 April 2012.

5 Article 51 of the UN Charter.

6 Security Council Resolutions, 1990, See, <http://www.un.org/Docs/scres/1990/ scres90.htm>, accessed on 23 April 2012.

7 Kosovo Statistical Office (2011). "Population estimates for Kosovo July 2011," Census 2011. See, <http://ask.rks-gov.net/en/kosovo-agency-of-statistics/ add-news/estimate-on-the-number-of-kosovo-population-2011>, accessed on 23 April 2012. 
international laws. The conflict has resulted in calamitous destruction of lives and economic resources in the country. Human rights are grossly violated. Children recruited as combatants. There is no any institutional responsibility towards persons with disability. The country has lost its place within the international community as a strategic location that plays a vital role in the regional and global maritime security. ${ }^{8}$

The following section of the article attempts to examine the above claim and to examine the effects of the war through the interview. Seven themes were selected for the interview. These are the effect of the war on the economy, the social affairs, health care, law enforcement, who are the most vulnerable people and the level of compliance of the warring factions with the International law. The interview also includes the collection of public opinion on the measures for the resolution of the war. The study focussed on the period between 1985 and 2015 because it is the most devastating period, due to the fact that the various factions in the war were being allegedly sponsored by outside forces. ${ }^{9}$

\section{RESEARCH INTERVIEW}

As earlier discussed, an in-depth semi-structured interview was conducted to ascertain the effects of the armed struggle and to interpret the complexity of the Yemeni society. Only seven respondents agreed to be questioned about the war. The respondents are made up of a group of researchers and intellectuals with various specialisations, occupations, and scientific backgrounds. The researchers could not get more respondents due to the fact that most of the people refused to be interviewed for fear of tribulation from the conflicting parties. However, the seven respondents are extensively knowledgeable about Yemeni society and the warfare. The interview helped the researcher to see the extent of human rights violation in the warfare. The face-to-face semistructured interview is viewed as the best substance of information aggregation. It requires real interaction between the researcher and the participants and it help out in collecting valid and reliable information as easily as their selfinsights, opinions and life experiences. The backdrop of the respondents is presented in the next table.

8 Convention on the Rights of the Child, adopted and opened for signature, ratification and accession by General Assembly resolution 44/25 of 20 November 1989.

9 Reuters (2014). "Exclusive: Saudi Suspends Aid to Yemen after Houthi Takeover," see, <http://www.reuters.com/article/us-yemen-saudi-aid-idUSKCN0JI10V2014 $1204>$, accessed on 4 December 2014. 
Table No. 1: Respondents Background

\begin{tabular}{|c|c|c|c|}
\hline Participants & 1 & 2 & 3 \\
\hline Age & 59 & 45 & 55 \\
\hline Occupation & Researcher & $\begin{array}{l}\text { Academic } \\
\text { Researcher }\end{array}$ & Researcher \\
\hline Marital Status & Married & Single & Married \\
\hline Participants & 5 & 6 & 7 \\
\hline Age & 58 & 59 & 56 \\
\hline Occupation & $\begin{array}{c}\text { Military } \\
\text { Researcher }\end{array}$ & $\begin{array}{l}\text { Academic } \\
\text { Researcher }\end{array}$ & $\begin{array}{l}\text { Academic } \\
\text { Researcher }\end{array}$ \\
\hline Marital Status & Married & Married & Married \\
\hline
\end{tabular}

Source: Interview Respondents.

\section{ECONOMIC EFFECT}

The ongoing armed conflict in Yemen has constituted total insecurity and unrest in the country and it has led to the destruction of many lives and properties. This is what fundamentally caused poverty that devastated livelihood Yemenis and the nation's economic resources. Poverty is being created and be used as a tactic to weaken and dominate one and another among the opponents (Justino, P., 2006: 61; Young, H. et al., 2005: 20). The respondents expressed their concern that the effect of wars on the economy has culminated in the loss of capital for investments in both the domestic and the foreign investment levels, and thereby inhibited the factors that are required to stimulate the economy that will lead to the development projects. This view is shared by most of the respondents. They included that the effect of the war is reflected in the decline of human capital. This is due to the fact that many qualified professionals were either killed, incapacitated or caused to flee the country. The first respondent maintained that the elimination of human capital was first loss and effect of the war on the country. This is despite that country spent enormous money on the training of the various cadres of the professionals that include scientists, academicians and the others. However, most of them were killed or lost in the war. The worst part if that all the institutions that can be used to produce similar human capital has been destroyed.

Another consequence of these losses is the increase in unemployment, which lead to increase in the rate of poverty among the citizens. This view is agreed upon by all the respondents. The sixth respondent stressed that: 
"The effects of the war on the economy has too many consequences among which is unemployment. He maintained that at the social level, extensive amounts of sources of wealth and infrastructure were knocked down by the war. Many foreign institutions and corporation have left the country, and domestic investments went abroad."

The effect of the poverty that was created by the war is very clear. This reflects especially in the increasing of homelessness, starvation and disruption of the education system. Another advert effect of the war is the increase in the percentage of crimes such as theft, kidnapping, looting and even prostitution, although the latter is not so overt due to social and customary restrictions. But the reality is the war as brought underground prostitution to the country. The second and fourth respondents elucidated this while responding to the question on:

"The advert effects of the war on the economy of Yemen. They explained that the effects include poverty, famine, devastation of economic resources, capital flight, the reluctance of investors to invest in a war-ravaged nation and the migration of highly qualified personnel. They maintained that can only be said to have caused by the war is destruction and wreckage. It has caused the people to become homeless and resulted in the loss of means of livelihoods. It has halted the educational system and destroyed public services. It produced criminal gangsters that engage in kidnapping, raping, looting and any other types of crimes."

The fifth respondent also agreed with them and included that:

"The Yemeni war as resulted in the world of poverty and unemployment, as comfortably as other negative social phenomena such as thefts and prostitution. The war is a clear and direct infringement of human rights".

Therefore, it can be reasoned from the answers of the respondents that the effects of the war on the economic system of the country include creation of poverty, devastation of economic resources, capital flight and migration of competent intellectual and highly skilled worker to other nations.

\section{SOCIAL EFFECTS}

The result of the war on family fabric is devastating. This is especially on women and children who are not directly taking part in warfare. Nevertheless, 
they suffer from the actions of the war, which include killings, injuries, abductions, physical abuse, displacement, the trauma of fear, anxiety, and family disintegration and etc. Family is the first victim of the war and most vulnerable to suffer from armed conflict as it can be seen in Yemen (Weinstein, J., \& Humphreys, M., 2008: 436). Only three respondents participated in this aspect of the interview. But at least two of them agree that the main reason for family disintegration is the loss of lives and displacement of family members or relocate to the domestic refugee centres, while another respondent viewed that the social impact of war is the restriction of movement and infringement of freedom of the people including violation of human rights. This result can be imaged in the increasing number of orphans and rate of widows. The first and second respondents remarked respectively that:

"Armed conflicts destroy human beings and hinder their movement or paralyse their work. Such conflicts have economic and social consequences such as family disintegration and increased the number of orphans" and "the war in Yemen has caused family disintegration and high rate of divorce..."

The tangible outcome of the interrogation of the social effect of the war as outlined by the respondent include the criminal offences of theft, prostitution and rape or the exposing of women or girls to the crime of assault. Another awful effect of the war is the emergence of underage street children who are the easy target for recruitment by the warring factions as combatants. The sixth respondent added that the social effects of, the war include:

"The loss of the breadwinner of a family which often leads to psychological traumas, family homelessness and children's drop out of schools. The war has adversely affected education system. At present the percentage ofvschool dropouts have reached 30 percent. This includes student dropouts from primary school, secondary school and the university level."

\section{VULNERABLE GROUP}

Several international conventions prohibit the use of force on women and children due to the reason that can not defend themselves in a situation of armed conflicts such as the civil war in Yemen $^{10}$ (al-Gasseer, N., Dresden, E.,

10 UNICEF (1996). "The Impact of Armed Conflict on Children," < http://www. unicef.org/graca/ >, accessed on 08 August 2016; UNICEF (2015). "The Impact of Conflict on Women and Girls in West and Central Africa," < http://www.unicef. org/emerg/files/Impact_conflict_women.pdf >, accessed on 08 August 2016. 
\& Brumbaugh, G. (2010: 7). In spite of this, brutalities and atrocities have been imposed on them in the Yemeni war. Therefore, the bulk of the respondents agrees that the most vulnerable group of citizenry in the Yemeni armed conflicts are women, children and the aged. In regard of this interrogation, three respondents alleged that women with political affiliation are the most exposed to cruelty in the warfare. They indicated that:

"Undoubtedly, the most vulnerable social groups in the war are women, minors, and the aged. The first victims are the civilians, political activists. Although all the people are victims, nevertheless, women, kids, and the aged are most vulnerable. The civilians are more affected than military force, who consider civilians to be nothing..."

More so, the fifth respondent added that the poor and lower income group, especially the unemployed, students and workers are the most exposed to the brutality as they are deprived of all economic means to support themselves. The respondent asserted that:

"The most vulnerable social groups in the Yemen armed conflicts are the urban poor, rural poor, citizens living in below standards, and the destitute. These groups fall into all other categories including, students, workers, men, women, and other civilians. That is because military personnel have salaries to live while the civilians have none..."

The sixth respondent is of the opinion that the most vulnerable group in the armed conflicts is the ignorant or the illiterate from the age of twenty to forty who are primarily poor and unemployed. He insisted that:

"This is primarily the unaware persons and ignorant, who is holding the gun's barrel. This group, especially from twenty to forty years of age, includes people with weak economic conditions and the unemployed. They involve themselves in the war for the sake of livelihood. Thus, the most vulnerable group is the poor..."

\section{EFFECT OF THE WAR ON HEALTH CARE}

A country with primarily poor health care, will certainly suffer more deterioration of the health care system in the situation of war. This is evident in the case of Yemen where there is no effective health care system, the war has disrupted the healthcare organization in totality. The citizens and the war combatants lack workable health care and are completely vulnerable. Most 
of the respondents concurred that the war has led to physical traumas such as mutilations and disabilities and psychological problems such as mental sickness, emotional imbalance and injury. The fourth respondent, for example, noted that:

"The armed conflict has substantial health effects on the civilians and the military personnel. This includes mutilations, disabilities, as well as mental and physical diseases. Even so, the adverse health effects are more austere on the kids and women because they are the most vulnerable groups to the effects of war. Moreover, many children are conscripted into the war and the armed conflict..."

The fifth respondent remark that:

"The war has heightened the agony of the masses. The masses that are wounded and mutilated during the peaceful youth protest are still not being cared for. There is no health care on normal days, let alone during wars. Moreover, officers that are injured in the war are suffering from psychological trauma due to lack of treatment and homelessness..."

The Yemeni war has also impacted negatively on the environment through the danger of the use of of landmines and toxic gas. The sixth respondent remark that:

"Armed conflict in poor countries is not only disasters, it is catastrophic due to the fact that there are no health insurance or laws on health insurance. This signifies that the diseases that are induced by the war cannot be healed or prevented. For instance, toxic gases with far-reaching effects are being employed in the war. The use of landmines also constitutes another problem. Even if armed conflict in Yemen ends the disaster of the landlines will remain for many years..."

\section{INFRACTIONS OF THE LAW}

The question of the breakdown of law and order was also asked in the interview. This is because Yemeni war involves the loss of many lives which indicates lack of orderliness and intensified hatred among the warring factions. This unfortunate state of affairs led to total collapse of security, orderliness, and 
effective policing. The violation of law in the country is widespread. ${ }^{11}$ On this question, the majority of the respondents agreed that the main indicator of the breakdown of law and order in the Yemeni war is the widespread of the cases of 'summary execution' of non-combatant prisoners and other civilians without any recourse to judicial process. The violation of fundamental rights and freedom is really dominant. The sixth respondent summarised this as the worst thing that was seen during the warfare. He claimed the Al-houts are mostly culpabable on the heinousness. He continued that during the 1994 clashes, the wounded were killed and prisoners' rights were neglected in violation of international law and norms. He added that the most horrible situation is that even the adult females and the children are intentionally shot down. Many women and children were helplessly used as a shield. In short, the war involves the broad and complete breakdown of both international and domestic laws and norms of war.

The third respondent added that the breakdown of law and order includes the violation of the political and civil rights of the people.

The fourth and fifth respondents summed up the answer on the question of the breakdown of law and order by giving the main reason for the matter as the collapse of the institutions that are responsible for enforcement of law. The fourth respondent stressed that:

"Law enforcement was all suspended, courts were shut down, torture, rape and killing were widespread, and jungle justice was prevalent..."

The indexes of the infraction of human rights during the war include torture, assault, and recruitment of children as fighters. The first responses described this as:

"Physical and mental degradation, the draft of the minors, suppression of freedom, and the violent death of prisoners..."

\section{CONFORMITY WITH INTERNATIONAL LAWS AND CONVENTIONS ON HUMAN RIGHTS}

During the armed struggle in Yemen, international humanitarian laws on human rights are grossly violated due to the believe of the warring parties that they will never be penalized for violation and flouting of the laws. The primary

11 Human.Rghts. Watch (2015). "World Report 2015: Yemen Events of 2014," see, $<$ https:www.hrw.org/world-report/2015/country-chapters/yemen>, accessed on 08 February 2015. 
cause for this is essentially the lack of awareness of fabric for the enforcement of the laws by the imposition of sanctions against the violators or perpetrators of war crimes and crimes against the mankind. ${ }^{12}$ Thus, most of the respondents agree that none of the conflicting parties complied with the international law. Two of the respondents supported this opinion by maintaining that:

"The conflicting parties, clans, the State, or political parties have not implemented or take international laws into account during the warfare. They are all culpable as far as violation of international laws and conventions are concerned during the war."

The third respondent gave the same grounds for the infraction of the jurisprudence. He put forward that one of such reasons is the deficiency of awareness about the laws and rules. He explained that:

"In third world nations that include Yemen, people are nevertheless living with medieval mentalities. Wars in such countries are considered on the savage and barbaric method. The rights of the people as guaranteed by the Shariah law, the Universal Declaration of Human Rights and the International Humanitarian Law are completely ignored. That is why war in those countries is disastrous."

Another reason, according to the respondent is the absence of international agencies or governing body that will be responsible for the enforcement of the international laws. The sixth respondent in his part observed that:

"International conventions were not adopted because of the absence of representatives of the international community."

He continued that:

"When the war break out, the international community abandons the country instead of using concerted efforts to restore law and order to it. Although, there are organisations such as the International Committee of the Red Cross, United Nations, and International Relief Organisation, who have local offices and venture to go to areas of fighting. However, their attitudes implied that they are not responsible for such enforcement given the fact

$12 \quad$ Farrell, T., \& Schmitt, O. (2012). "The Causes, Character and Conduct of Armed Conflict and the Effects On Civilian Populations, 1990-2010," <http://www. refworld.org/docid/4f8c3fcc2.html >, accessed on 08 August 2016. 
that they never cover any human rights infringements against the warring parties."

\section{CONCLUSION}

To sum up, the foregoing is a brief introduction to the negative effects of the Yemeni war in terms of its violation of custom, ethics and rules of war in both of the Shariah and international laws. The most significant aspect of the violation of rules of laws in the war is that it is not for the purpose of 'selfdefence' which the main justification for 'use of force under the laws. The interviews that were conducted in the research further buttressed the argument the war does not take rules of law into account in any respect. The respondents unanimously agreed that the parties in the wars do not have any regard for human rights. Their action result in a devastating effect on the population in terms of deprivation of lives and economic resources. The negative impact of the war reflects on all members of the society, and most especially, women and children. The war has inflicted the problems of poverty, family decay, physical and psychological illness, and the increased rate of crime on the masses. More or less of the negative result of the war on the economy is the migration of professionals to other nations and capital flight for both foreign and domestic investments.

This in turn resulted in acute poverty, unemployment and homelessness, which have devastated the health maintenance organization and societal welfare. There are problem of improper execution of captives and civilians and restriction of human rights which is a consequence of the total breakdown of law and orderliness in the state. It is, therefore, concluded that there is a need for the creation of a platform for awareness about the importance of respect of human rights, education about ethics, norms and rules of war under Shariah and International law, among the warring parties, as a measure to mitigate the suffering of the people. This responsibility should be admitted in the duties and obligation of the international bodies and agencies that are in the country given the fact that they enjoy immunity against attack from the warring parties. Steps must be taken to bring the war to an end due to the fact that the lives of innocent women, children, the aged, and the civilians are unnecessarily wasted on a daily basis. The warring parties should be conveyed to a roundtable to collectively chart the path ahead for the nation. 


\section{REFERENCES}

Aboul-Enein, H. Yousuf \& Zuhur, Sherifa, (2004), Islamic Rulings on Warfare, Strategic Studies Institute, US Army War College. Darby, U.S.A.: Diane Publishing Co.

Abraham D. Sofaer \& Kori Schake, "Preventive Force: Issues for Discussion," see, <https://www.princeton.edu/ ppns/conferences/reports/pf_paper. pdf $>$, accessed on 10 July 2016.

Afsaruddin, Asma (2007). "Views of Jihad Throughout History." Religion Compass, vol. 1 (1).

Ahmed Al-Dawoody (2011). The Islamic Law of War: Justifications and Regulations. United States: Palgrave, Macmillan.

Al-Gasseer, N., Dresden, E., \& Brumbaugh, G. (2010). "Status of Women and Infants in Complex Humanitarian Emergencies." Midwifery \& Women's Health, vol. 49 (1).

Bradley J. Cook \& Michael Stathis (2012). "Democracy and Islam: Promises and Perils for the Arab Spring Protests." Journal of Global Responsibility, vol. 3 (2), 175-186.

Charter of the United Nations and Statute of the International Court Of Justice, Chapter VII, Action with Respect to Threats to the Peace, Breaches of the Peace, and Acts of Aggression, Article 51, p 10.

Convention on the Rights of the Child, adopted and opened for signature, ratification and accession by General Assembly resolution 44/25 of 20 November 1989.

Cordisman, A., Rebert, M., \& Mohamed, O. (2013). Yemen and U.S. Security. Washington, D.C.: Centre for Strategic Study and International Studies.

El Daly, Okasha (2004). Egyptology: The Missing Millennium: Ancient Egypt in Medieval Arabic Writings. London: Taylor \& Francis Group.

Farrell, T., \& Schmitt, O. (2012). "The Causes, Character and Conduct of Armed Conflict and the Effects on Civilian Populations, 1990-2010." http://www.refworld .org/docid/4f8c3fcc2.html., accessed on 25 April 2012.

General Treaty for the Renunciation of War or the World Peace Act, 1928. See, $<$ http://history.state.gov/>, accessed on 25 April 2012.

Grut, L., \& Ingstad, B. (2006). This is My Life: Living with A Disability in Yemen. World Bank. Norway: SINTEF Health Research.

Hassan Hathout (n.d.). War Ethics in Islam. Los Angeles: Minarate Publishing House. 
http://avalon.law.yale.edu/imt/jack10.asp>, accessed on 25 April 2012.

Human.Rights.Watch (2015). "World Report 2015: Yemen Events of 2014," see, <https:www.hrw.org/world-report/2015/country-chapters/yemen>, accessed on 08 February 2015.

Judge Weeramantry, Christopher G. (1997). Justice Without Frontiers. Leiden, Netherlands: Brill Publisher.

Justino, P. (2006). On the Links Between Violent Conflict and Chronic Poverty: How Much Do We Really Know the Institute of Development Studies, At the University of Sussex. Brighton BN1 9RH, UK: Chronic Poverty Research Centre.

Kelsay, J. (2003). "Al-Shaybani and the Islamic Law of War." Journal of Military Ethics (Routledge), vol. 2 (1).

Khaled Abou El Fadl (1999). "The Rules of Killing at War: An Inquiry into Classical Sources." The Muslim World, vol. 89 (2).

Kosovo Statistical Office (2011). "Population estimates for Kosovo July 2011," Census 2011, accessed on 2011.

Louis Rend Beres (2016). "On Assassination as Anticipatory Selfdefense: The Case of Israel," Hofstra Law Review, vol. 20 (321).

Machel, G., \& Erlichman, S. (1997). "The Impact of Armed Conflict on Children." Proquest Social Science Journals, vol. 26 (6).

Muhammad Naqib Ishan Jan (2011). Use of Force in International Law. Malaysia: CLJ Publication.

Patricia Crone (2001-2006). Encyclodepia of Qur'an, War Article. Leiden, Netherlands: Brill Publishers.

Rajab, N., \& Azer, S. (2010). "In the Name of National Security: Human Rights Violations in Yemen." International Federation of Human Rights.

Reuters, "Exclusive: Saudi suspends aid to Yemen after Houthi takeover," http://www.reuters.com/article/us-yemen-saudi-aididUSKCN0JI10V20141204, accessed on 4 December 2014.

Sanaa Centre (2015). United States Policy \& Yemen's Armed Conflict. Sanaa: Sana'a Center for Strategic Studies.

Tabari, Al (1993). The Conquest of Arabia. New York, United States: State University of New York Press, Albany.

Terrill, A. (2012). The Conflict in Yemen and U.S. National Security. United States: U.S. Army's Institute for Strategic and National Security Research and Analysis. 
UNICEF (2015). "The Impact of Conflict on Women and Girls in West and Central Africa," United Nations Children's Fund (UNICEF), accessed on 5 November 2015.

United Nations, <http://www.un.org/en/documents/charter/chapter1.shtml>, accessed on 25 April 2012.

Weinstein, J., \& Humphreys, M. (2008). "Who Fights? The Determinants of Participation." American Journal of Political Science, vol. 52 (2).

Young, H., Osman, A. M., Aklilu, Y., Dale, R., \& Badr, B. (2005). Darfur: Livelihoods Under Siege. Tufts University and Ahfad University for Women. Omdurman, Sudan: Feinstein International Famine Center.

\section{List of Statutes}

Article 51 of the UN Charter. 
Journal of Shariah Law Research (JSLR) 